\title{
The Association of Panton-Valentine leukocidin and mecA Genes in Methicillin-Resistant Staphylococcus aureus Isolates From Patients Referred to Educational Hospitals in Ahvaz, Iran
}

\author{
Hossein Motamedi ${ }^{1, *}$; Seyyed Soheil Rahmat Abadi ${ }^{1}$; Seyyed Mojtaba Moosavian ${ }^{2}$; Maryam \\ Torabi $^{2}$ \\ ${ }^{1}$ Department of Biology, Shahid Chamran University, Ahvaz, IR Iran \\ ${ }^{2}$ Department of Microbiology, Jundishapur University of Medical Sciences, Ahvaz, IR Iran \\ ${ }^{*}$ Corresponding author: Hossein Motamedi, Department of Biology, Shahid Chamran University, Ahvaz, IR Iran. Tel: +98-6133331045, Fax: +98-6133331045, \\ E-mail:motamedih@scu.ac.ir; hhmotamedi@yahoo.com
}

Received: July 13, 2014; Revised: September 5, 2014; Accepted: September 27, 2014

\begin{abstract}
Background:Staphylococcus aureus, an important human pathogen is one of the main causative agents of nosocomial infection. Virulence genes play a major role in the pathogenicity of this agent and its infections. Methicillin-Resistant Staphylococcus aureus (MRSA) isolates are major challenge among infectious agents that can cause severe infections and mortality. Methicillin-resistant $S$. aureus produces a unique type of Penicillin Binding Protein 2a (PBP2a) that has low affinity for $\beta$-lactam antibiotics. Most of the MRSA bacterial strains can also produce a leukotoxin as Panton-Valentine Leukocidin (PVL) that increases the virulence of MRSA strains and can cause severe necrotic pneumonia. The presence of $p v$ l gene is a genetic marker for the MRSA populations.

Objectives: The aim of this study was to explore the association of $p v l$ and mecA genes in clinical isolates of MRSA.

Materials and Methods: Fifty MRSA isolates were collected from 200 clinical samples from three different educational hospitals in Ahvaz, Iran, and identified by biochemical tests including catalase, oxidase, tube coagulase, mannitol fermentation, and sensitivity to furazolidone, resistance to bacitracin, PYR test and Voges-Proskauer test. Their resistance to methicillin was evaluated using the disc diffusion method. DNA was extracted by boiling and then the presence of $p v l$ and mecA genes was investigated by the polymerase chain reaction method using specific primers.

Results: The results revealed that mecA and $p v$ lgenes were positive for $15(30 \%)$ and $3(6 \%)$ of the isolates, respectively. None of mecA positive isolates was positive for $p v l$ gene.

Conclusions: It can be concluded from these results that fortunately the prevalence of $p v l$ gene is low in MRSA isolates in this region and there is no association between the presence of $p v l$ and mecA genes in these isolates.
\end{abstract}

Keywords: MRSA; Iran; Virulence Factor; Methicillin Resistance; Panton Valentine Leukocidin

\section{Background}

Among the etiologic agents of infectious disease, Staphylococcus aureus, especially Methicillin-Resistant Staphylococcus aureus (MRSA) strains are the main agents of human infections (1). This pathogen can cause nosocomial infection in such a manner that it is the most common pathogen isolated from patients in hospitals that can cause wide range of infections from skin and soft tissue infections till toxic shock syndrome and life threatening syndromes. During the end of 1990s, increasing of S. aureus infections was led to isolation of MRSA (2-5). Nearly, all $S$. aureus isolates produce various toxins and enzymes that are important in the pathogenicity of this bacterium $(6,7)$. With the emergence of resistant strains at 1961 that had multidrug resistance, the treatment of $S$. aureus infections had been paid more attention. The MRSA stains are widely distributed around the world that shows their resistance to both penicillins and cephalosporins $(8,9)$.
The MRSA produces a unique type of Penicillin Binding Protein 2a (PBP2a) that has low affinity for $\beta$-lactam antibiotics $(10,11)$. Most of MRSA strains can also produce a leukotoxin as Panton-Valentine Leukocidin (PVL) that increases their virulence and can cause severe necrotic pneumonia $(8,12)$. Pathogenicity of $S$. aureus results from the surface cell wall structures and different exoproteins that PVL is one of the most important of them for overcoming host immunity and disease progress (13). Pore forming toxins perforate membranes of host cells, mainly the plasma membrane and also intracellular organelle membranes. They directly kill target cells, in order to intracellular delivery of other bacterial or external factors, releasing nutrients or escaping from phagosomal space. Panton-valentine leukocidin is a member of pore forming toxins that targets host leukocytes. The PVL- producing strains are commonly involved in the skin and soft tissue infections as well as

Copyright (C) 2015, Ahvaz Jundishapur University of Medical Sciences. This is an open-access article distributed under the terms of the Creative Commons Attribution-NonCommercial 4.0 International License (http://creativecommons.org/licenses/by-nc/4.0/) which permits copy and redistribute the material just in noncommercial usages, provided the original work is properly cited. 
able to cause life threatening infections like pneumonia $(7,8,12)$. Two open reading frames are responsible for coding PVL, i.e. lukS-pv and lukF-pv. The presence of $p v l$ gene is a genetic marker for the MRSA populations (14). Recently, reports about infections caused by $p v l$-positive strains have been increased that necessitate investigations about the prevalence of this virulent marker among MRSA strains in hospital and also community acquired infections.

\section{Objectives}

The aim of the present study was to discover the association of $p v l$ and mecA in MRSA strains isolated from hospitalized patients in three educational hospitals of Ahvaz City, Iran.

\section{Materials and Methods}

\subsection{Sampling}

Fifty S. aureus isolates were collected from patients in three educational hospitals of Ahvaz, including Imam Khomeini, Golestan and Taleghni hospitals. These samples were obtained from 200 samples collected from different sections of the above-mentioned hospitals including Outpatient Department (OPD), skin, men surgery, ophthalmology, nephrology, pediatric, women, orthopedic, ear, nose and throat (ENT), neonates and internal medicine. Samples were collected from skin lesions, blood cultures, burns, intravenous catheters, wound drainages, abscesses, tracheal secretions, synovial fluids, ocular secretions and urines. These isolates were identified based on standard morphological and biochemical tests including catalse, oxidase, tube coagulase, mannitol fermentation, sensitivity to furazolidon, resistance to bacitracine, PYR test and Voges-Proskauer (15).

\subsection{Determining Antibiotic Susceptibility}

In order to determine methicillin resistance of isolates Muller-Hinton Agar (MHA, Merck, Germany) screening test was used according to CLSI (clinical and laboratory standards institute) (16). Briefly, a 0.5 McFarland suspension was prepared from pure culture of isolates and then cultured on MHA containing oxacillin $(6 \mu \mathrm{g} / \mathrm{mL})$. For this purpose using a sterile swab the bacterium was inoculated as a dot with a $10-15 \mathrm{~mm}$ diameter and a strike culture was prepared on the other part of plate and incubated at $35^{\circ} \mathrm{C}$. The results were studied after 24 and 48 hours of incubation. Growth of only one colony on this culture medium revealed methicillin resistance of that isolate. Staphylococcus aureus ATCC 29213 as the negative control and sensitive to methicillin and S. aureus ATCC 33591 as the positive control and resistant to methicillin were used in all experiments. Furthermore, the susceptibility of isolates to oxacillin was surveyed using the standard Kirby-Bauer disc diffusion method (17).

\subsection{DNA Extraction}

The isolates were cultured in Trypticase Soy Broth (TSB, Merck, Germany) for $18 \mathrm{~h}$ at $37^{\circ} \mathrm{C}$. Then, $1.5 \mathrm{~mL}$ of culture was centrifuged (12000 rpm, 10 minutes) and the precipitate was dissolved in one $\mathrm{mL}$ deionized water and boiled for 20 minutes. After centrifugation ( $5000 \mathrm{rpm}, 5$ minutes) the supernatant was slowly mixed with phenolchloroform-isoamyl alcohol (1:24:25) at $1: 1$ ratio and the aqueous phase was harvested by centrifugation at 13000 rpm, 30 seconds. Cold isopropanol was added to aqueous phase $(60.100, \mathrm{v} / \mathrm{v})$ and stored overnight at $-22^{\circ} \mathrm{C}$. The DNA was then precipitated and washed subsequently with absolute and 70\% ethanol. Finally, DNA was air-dried at $37^{\circ} \mathrm{C}$ and dissolved in $200 \mu \mathrm{L}$ sterile deionized water and stored at $-22^{\circ} \mathrm{C}$ till experiments (18).

\subsection{Polymerase Chain Reaction}

Polymerase Chain Reaction (PCR) was performed in a final $25 \mu \mathrm{L}$ volume reaction containing PCR buffer (10x), Magnesium Chloride $\left(\mathrm{MgCl}_{2}\right)(2 \mathrm{mM})$, Deoxynucleotide Triphosphates (dNTPs) (0.2 mM), forward and reverse primers $(10 \rho \mathrm{mol} / \mu \mathrm{L})$, template DNA $(1 \mu \mathrm{L})$, Taq DNA polymerase ( 1.5 $\mathrm{u})$ and deionized water. The PCR method was performed in thermal cycler (Bio-Rad, USA) according to the following program: initial denaturation $\left(94^{\circ} \mathrm{C}, 2\right.$ minutes), 35 cycles each composed of initial denaturation $\left(94^{\circ} \mathrm{C}\right.$, 30 seconds), primer annealing $\left(55^{\circ} \mathrm{C}, 45\right.$ seconds $)$ and extension $\left(72^{\circ} \mathrm{C}\right.$, 75 seconds) and a final extension $\left(72^{\circ} \mathrm{C}, 4\right.$ minutes $)(19)$. Positive control for mecA and $p v l$ genes and negative control (distilled water) were also regarded in each series of PCR reaction. The PCR product was subjected to electrophoresis in $1 \%$ agarose gel containing DNA safe stain and documented using gel documentation (UVI TEC, Cambridge, UK).

\section{Results}

From a total of 50 samples, 27 samples (54\%) were belonged to Imam Khomeini Hospital, 16 samples (32\%) from Golestan Hospital and 7 samples (14\%) from Taleghani Hospital. According to the patient gender, 26 samples (52\%) were isolated from men while 24 samples (48\%) were from women. The number of samples from different clinical specimens and hospital sections are presented in Tables 2 and 3, respectively.

\begin{tabular}{|c|c|c|}
\hline Primer & Sequence & Base \\
\hline $\operatorname{MecA1}^{\mathrm{a}}$ & $5^{\prime}$ GTAGAAATACT GAACGT CCGATAA 3` & 24 \\
\hline MecA2 & $5^{\prime}$ CCAATTCCACATTGTTTCGGTCTAA $3^{\prime}$ & 25 \\
\hline Luk-PV1 & $5^{`}$ ATCATTAGGTAAAATGTCTGGACATGATCCA3' & 31 \\
\hline Luk-PV2 & $5^{\prime}$ GCATCAAGTGTATTGGATAGCAAA AGC $3^{\prime}$ & 27 \\
\hline
\end{tabular}


Table 2. The Source of Staphylococcus aureus Isolates in Clinical Samples

\begin{tabular}{|lc|}
\hline Clinical Sample & Number of Isolates \\
\hline Skin lesions & 11 \\
\hline Blood cultures & 9 \\
\hline Burns & 6 \\
\hline Urines & 3 \\
\hline Abscesses & 3 \\
\hline Tracheal Secretions & 3 \\
\hline Synovial Fluids & 2 \\
\hline Ocular Secretions & 3 \\
\hline Intravenous Catheters & 6 \\
\hline Wound Drainages & 4 \\
\hline
\end{tabular}

Table 3. Distribution of Samples in Different Hospital Wards ${ }^{\text {a }}$

\begin{tabular}{lc}
\hline Ward & Number of Isolates \\
\hline OPD & 13 \\
\hline Skin & 13 \\
\hline Men surgery & 1 \\
\hline Ophthalmology & 3 \\
\hline Nephrology & 8 \\
\hline Pediatric & 3 \\
Women & 3 \\
\hline Orthopedic & 2 \\
\hline ENT & 2 \\
\hline Neonates & 1 \\
\hline Internal Medicine & 1
\end{tabular}

a Abbreviations: OPD, Outpatient Department; ENT, Ear, Nose and Throat.

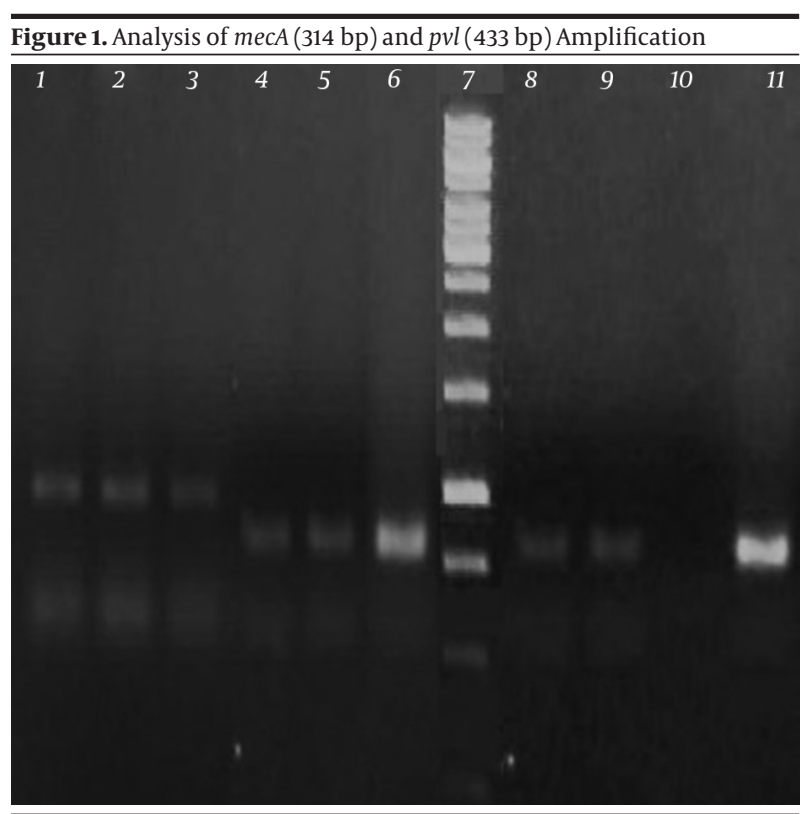

1: Positive Control for $p v l ; 2$ and 3: Positive $p v l$ Clinical Isolates; 4, 5, 6, 8 and 9: Positive mecA in Clinical Isolates; 7:100 bp Molecular Weight Marker; 10 : Negative Control (Distilled Water) and 11: Positive Control for mecA.

The results of antibiotic susceptibility tests revealed that all isolates were resistant to methicillin. Following PCR reaction with mecA and pvl specific primers, $314 \mathrm{bp}$ and $433 \mathrm{bp}$ PCR products were produced for mecA and $p v l$ genes, respectively (Figure 1).
Table 4. Results of mecA and pvl Screening in 50 MethicillinResistant Staphylococcus aureus Isolates

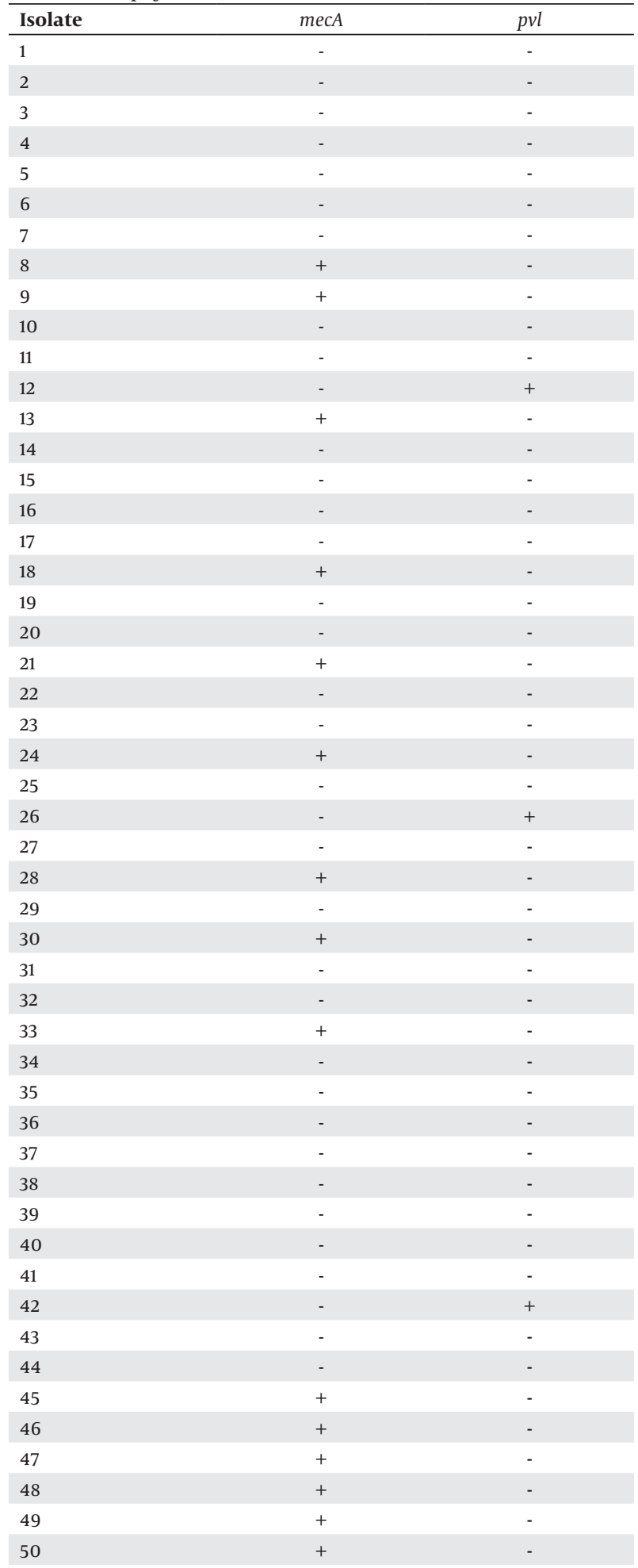

Table 4 shows the total number of MRSA isolates and their mecA and $p v l$ markers. Based on the obtained results, 30\% (15 samples) of MRSA strains were positive for mecA gene while 6\% (3 samples) had pvl gene. None of the samples had simultaneously both virulence markers. 


\section{Discussion}

Staphylococcus aureus is one of the most common pathogens that have been isolated from patients in hospitals, especially MRSA strains are among important nosocomial infections for humans (1). Having knowledge about the prevalence of MRSA and their virulence factors is useful for treatment and control of community and hospital acquired S. aureus infections. Following the emergence of MRSA strains, molecular studies showed that some of these isolates carry $p v l$ gene (20). The $p v l$ positive strains lead to infections with different clinical appearance even in immunocompromised patients lead to necrotic pneumonia, which its mortality can be as much as $75 \%$ (8). Therefore, frequent monitoring of this pathogen, its antibiotic susceptibility and determining their virulence factors is of great importance in control and treatment of infections.

According to the results of this study, only $30 \%$ of isolates identified as MRSA were positive for mecA gene. This explains that it maybe mecA positive MRSA isolates have different mechanism for methicillin resistance than mecA. These results are in agreements with other reports such as reported by Bagdonas et al. in Lithuania (23.4\%) (21), Turnidge et al. in Australia (24\%) (22), Li et al. in China (12\%) (23) and also in different parts of Iran, e.g. Fatholahzadeh et al. in Tehran (36\%) (24) and by Japoni et al. in Shiraz (43\%) (25). However, the frequency of mecA positive isolates in this study is more than the results of Bagdonas et al. Turnidge et al. and Li et al. while is less than the results obtained by Fatholahzadeh et al. (2009) and Japoni et al. This finding is a hopeful result that the frequency of mecA in Ahvaz is yet less than other studied areas of Iran. The occurrence of $p v l$ gene in previous studies has been reported from $2 \%-35 \%(26,27)$. In comparison the obtained results for $p v l$ gene in the present study is near to the lower limit obtained from similar studies. No association between mecA and $p v l$ genes was found in our study. It is possible that mecA and $p v l$ genes but not both of them be present on the chromosome of clinical isolates of S. aureus.

The obtained results in the present study are in agreement with the finding of Okon et al. (27) and Terry Alli et al. (9) that reported no $p v l$ positive strain is there among tested MRSA strains. Okon et al. (27) have suggested it is maybe that resistance determinants be carried on other mobile elements, such as plasmids, transposons, and phages; so, their elimination from bacterial cell would result in the absence of $m e c A$ gene and consequently no association with $p v l$ gene. Affolabi et al. (28) also reported no significant association between $p v l$ and mecA in $S$. aureus isolates from Cotonou. However, the $p v l$ gene has been reported in some MRSA in other studies $(29,30)$.

According to the results of this study, PCR assay for MRSA gene can be useful for definite diagnosis of MRSA strains. Identification of mecA positive strains can be used as a guide for separating infected patients from others in hospital environment in order to prevent gene transfer among clinical strains and also distribution of virulent factors.

\section{Acknowledgements}

The authors wish to thank the research vice chancellor of Shahid Chamran University in Ahvaz City, Iran, for providing research grant (Grant No. 874095).

\section{Authors' Contributions}

Hossein Motamedi: Study design, laboratory experiment, and manuscript preparation. Seyyed Soheil Rahmat Abadi: Laboratory experiments. Seyyed Mojtaba Moosavian: Sample providing. Maryam Torabi: Sample providing.

\section{Funding/Support}

This study was funded and supported by Shahid Chamran University of Ahvaz, Iran.

\section{References}

1. David MZ, Daum RS. Community-associated methicillin-resistant Staphylococcus aureus: epidemiology and clinical consequences of an emerging epidemic. Clin Microbiol Rev. 2010;23(3):616-87.

2. Dash N, Panigrahi D, Al Zarouni M, Yassin F, Al-Shamsi M. Incidence of community-acquired methicillin-resistant Staphylococcus aureus carrying Pantone-Valentine leucocidin gene at a referral hospital in United Arab Emirates. APMIS. 2014;122(4):341-6.

3. Sanchini A, Del Grosso M, Villa L, Ammendolia MG, Superti F, Monaco M, et al. Typing of Panton-Valentine leukocidin-encoding phages carried by methicillin-susceptible and methicillinresistant Staphylococcus aureus from Italy. Clin Microbiol Infect. 2014;20(11):0840-6.

4. Carleton HA, Diep BA, Charlebois ED, Sensabaugh GF, PerdreauRemington F. Community-adapted methicillin-resistant Staphylococcus aureus (MRSA): population dynamics of an expanding community reservoir of MRSA. J Infect Dis. 2004;190(10):1730-8.

5. Srinivasan A, Seifried S, Zhu L, Srivastava DK, Flynn PM, Shenep JL, et al. Panton-Valentine leukocidin-positive methicillin-resistant Staphylococcus aureus infections in children with cancer. Pediatr Blood Cancer. 2009;53(7):1216-20.

6. Khosravi AD, Hoveizavi H, Farshadzadeh $\mathrm{Z}$. The prevalence of genes encoding leukocidins in Staphylococcus aureus strains resistant and sensitive to methicillin isolated from burn patients in Taleghani Hospital, Ahvaz, Iran. Burns. 2012;38(2):247-51.

7. Los FC, Randis TM, Aroian RV, Ratner AJ. Role of pore-forming toxins in bacterial infectious diseases. Microbiol Mol Biol Rev. 2013;77(2):173-207.

8. Yanagihara K, Kihara R, Araki N, Morinaga Y, Seki M, Izumikawa $\mathrm{K}$, et al. Efficacy of linezolid against Panton-Valentine leukocidin (PVL)-positive meticillin-resistant Staphylococcus aureus (MRSA) in a mouse model of haematogenous pulmonary infection. Int J Antimicrob Agents. 2009;34(5):477-81.

9. Terry Alli OA, Ogbolu DO, Mustapha JO, Akinbami R, Ajayi AO. The non-association of Panton-Valentine leukocidin and mecA genes in the genome of Staphylococcus aureus from hospitals in South Western Nigeria. Indian J Med Microbiol. 2012;30(2):159-64.

10. Kim MH, Lee WI, Kang SY. Detection of methicillin-resistant Staphylococcus aureus in healthcare workers using real-time polymerase chain reaction. Yonsei Med J. 2013;54(5):1282-4.

11. Ba X, Harrison EM, Edwards GF, Holden MT, Larsen AR, Petersen $\mathrm{A}$, et al. Novel mutations in penicillin-binding protein genes in 
clinical Staphylococcus aureus isolates that are methicillin resistant on susceptibility testing, but lack the mec gene.J Antimicrob Chemother. 2014;69(3):594-7.

12. van der Meeren BT, Millard PS, Scacchetti M, Hermans MH, Hilbink M, Concelho TB, et al. Emergence of methicillin resistance and Panton-Valentine leukocidin positivity in hospital- and community-acquired Staphylococcus aureus infections in Beira, Mozambique. Trop Med Int Health. 2014;19(2):169-76.

13. Neela V, Ehsanollah GR, Zamberi S, Van Belkum A, Mariana NS. Prevalence of Panton-Valentine leukocidin genes among carriage and invasive Staphylococcus aureus isolates in Malaysia. Int J Infect Dis. 2009;13(3):e131-2.

14. Chen FJ, Hiramatsu K, Huang IW, Wang CH, Lauderdale TL. Panton-Valentine leukocidin (PVL)-positive methicillin-susceptible and resistant Staphylococcus aureus in Taiwan: identification of oxacillin-susceptible mecA-positive methicillin-resistant S. aureus. Diagn Microbiol Infect Dis. 2009;65(4):351-7.

15. Tile PM. Bailey \& Scott's Diagnostic Microbiology. New York: Mosby; 2013.

16. Clinical and laboratory standard institute. Methods for dilution antimicrobial susceptibility tests for bacteria that grow aerobically. Wayne: 2006.

17. Clinical and laboratory standard institute. Performance standards for antimicrobial susceptibility testing; Twenty second informational supplement. Wayne: 2012.

18. Sambrookm J, Fritsch EF, Maniatis T. Molecular cloning, A Laboratorry Manual.New York: Cold Spring Harbor Laboratory Press; 1989.

19. McClure JA, Conly JM, Lau V, Elsayed S, Louie T, Hutchins W, et al. Novel multiplex PCR assay for detection of the staphylococcal virulence marker Panton-Valentine leukocidin genes and simultaneous discrimination of methicillin-susceptible from -resistant staphylococci. J Clin Microbiol. 2006;44(3):1141-4.

20. Shore AC, Tecklenborg SC, Brennan GI, Ehricht R, Monecke S, Coleman DC. Panton-Valentine leukocidin-positive Staphylococcus aureus in Ireland from 2002 to 2011: 21 clones, frequent importation of clones, temporal shifts of predominant methicillinresistant S. aureus clones, and increasing multiresistance. J Clin Microbiol. 2014;52(3):859-70.

21. Bagdonas R, Tamelis A, Rimdeika R, Kiudelis M. Analysis of burn patients and the isolated pathogens. Lithuanian Surg. 2004;

\section{2(3):190-3.}

22. Turnidge JD, Nimmo GR, Pearson J, Gottlieb T, Collignon PJ, Australian Group on Antimicrobial R. Epidemiology and outcomes for Staphylococcus aureus bacteraemia in Australian hospitals, 2005-06: report from the Australian Group on Antimicrobial Resistance. Commun Dis Intell Q Rep. 2007;31(4):398-403.

23. Li J, Zeng H, Xu X. [A study of methicillin - resistant staphylococcus aureus (MRSA) in a burn unit with repetitive - DNA - sequence - based PCR fingerprinting]. Zhonghua Shao Shang Za Zhi. 2001;17(2):88-90.

24. Fatholahzadeh B, Emaneini M, Aligholi M, Gilbert G, Taherikalani $\mathrm{M}$, Jonaidi N, et al. Molecular characterization of methicillin-resistant Staphylococcus aureus clones from a teaching hospital in Tehran.Jpn J Infect Dis. 2009;62(4):309-11.

25. Japoni A, Alborzi A, Orafa F, Rasouli M, Farshad S. Distribution patterns of methicillin resistance genes (mecA) in Staphylococcus aureus isolated from clinical specimens. Iran Biomed J. 2004;8(4):173-8.

26. Melles DC, Gorkink RF, Boelens HA, Snijders SV, Peeters JK, Moorhouse MJ, et al. Natural population dynamics and expansion of pathogenic clones of Staphylococcus aureus. J Clin Invest. 2004;114(12):1732-40.

27. Okon KO, Basset P, Uba A, Lin J, Oyawoye B, Shittu AO, et al. Cooccurrence of predominant Panton-Valentine leukocidin-positive sequence type (ST) 152 and multidrug-resistant ST 241 Staphylococcus aureus clones in Nigerian hospitals. J Clin Microbiol. 2009;47(9):3000-3.

28. Affolabi D, Odoun M, Faïhun F, Damala RL, Ahovegbe L, Prudence Wachinou A. Non-association of the presence of panton-valentine leukocidin gene with antimicrobial-resistance in Staphylococcus aureus isolates in Cotonou, Benin. Int $J$ of Curr Res. 2014;6(1):4617-20.

29. San Juan JA, Cabugao DBG, Dabbay B, Cabrera EC. Occurrence of Methicillin-Resistant Staphylococcus aureus (MRSA) among the Health Workers of Rizal Provincial Hospital and Characterization for the Presence of luks-lukf PVL Gene. Philippine J Sci. 2012;141(2):157-63.

30. Rebollo-Perez J, Ordonez-Tapia C, Herazo-Herazo C, Reyes-Ramos N. Nasal carriage of Panton Valentine leukocidin-positive methicillin-resistant Staphylococcus aureus in healthy preschool children. Rev Salud Publica (Bogota). 2011;13(5):824-32. 